\title{
REPAIRABLE SPARE PARTS FLOW IN A MULTI-ECHELON INVENTORY SYSTEM
}

\author{
Milić R. Milićević ${ }^{a}$, Vlada S. Sokolović ${ }^{b}$, Marjan A. Milenkov ${ }^{c}$, \\ University of Defence in Belgrade, Military Academy \\ a e-mail: milic.milicevic@mod.gov.rs, \\ ORCID iD: ienttp://orcid.org/0000-0002-9405-4151 \\ b e-mail: vlada.sokolovic@va.mod.gov.rs, \\ ORCID iD: ichttp://orcid.org/0000-0003-0782-0506 \\ c e-mail: marjan.milenkov@va.mod.gov.rs \\ ORCID iD: (i)http://orcid.org/0000-0003-2054-0525
}

DOI: $10.5937 /$ vojtehg64-8204

FIELD: Computer Sciences, Decision Theory \& Quantitative Methods ARTICLE TYPE: Original Scientific Paper ARTICLE LANGUAGE: English

\begin{abstract}
:
This paper considers the problem of changing the value of selected characteristics for the operation of a two-level inventory system of maintainable parts depending on the flow of regenerated components in the inventory system. We analyzed the influence of the flow of regenerated components on the value of the coefficient of peripheral storage fill-rate, total costs and the average waiting time in the queue in peripheral warehouses, at different nominal values of the stocks in central and peripheral warehouses. The demand for spare parts in the peripheral warehouses is dependent on seasonal changes, modeled with an appopriate probability distribution.
\end{abstract}

Key words: modeling, multi-echelon inventory system, repairable spare parts, simulation, spare parts.

ACKNOWLEDGEMENT: This work has been supported by the University of Defence in Belgrade, Ministry of Defence, of the Republic of Serbia under project VA-TT/6/13-15. 


\section{Introduction}

Repairable assemblies are parts of complex technical systems that can be repaired after failure. Repairable assemblies, the repair of which is costeffective, have a special significance within the inventory spare parts system for a number of reasons. Some of the reasons are: the price of assembly recovery is in most cases lower than the price of a new one, the aggregation principle of maintenance is possible, highly qualified personnel at lower maintenance levels is reduced, the time of the assembly not in use is reduced, the amount of spare parts for the repair of components that must be kept in the inventory is also reduced, etc. (Milićević, 2000).

In a complex spare parts inventory system, repairable assemblies are commonly deployed into a few hierarchically organized levels. At the top of the hierarchy, there is one central warehouse that supplies more peripheral warehouses at the lower levels of hierarchy.

Depending on a system organization, communication and exchange of repairable parts between warehouses at the same level of hierarchical organization is either allowed or forbidden. Repairable assemblies, after failure, if it is cost-effective, are sent for repair to a workshop. After repair, assemblies are returned to the system in the central warehouse, in the peripheral warehouse, or combined, within the both hierarchical levels.

For a successful management of a multi-echelon inventory of maintainable parts, it is necessary to know the characteristics of system functioning and the intensity of changes in the inventories, depending on the changes in conditions of system functioning. Of all the conditions in which the system works, possibilities of replenishment and disorders of demand are most commonly of crucial importance. The characteristics of system functioning are also affected by a nominal level of inventories in a warehouse. Predicting management actions depends on the changes in system characteristics as well as on the changes in the conditions of system functioning. The following characteristics of the inventory system can be identified as relevant: the fill-rate of storage, the number of requests and the waiting time, the cost of the system and the probability of waiting in line until a certain time. Also, the characteristics of system functioning are affected by the flow of repaired components, and the place of their return into the system.

Determining the relationship between the properties of the system and the change in the intensity of demand for a repairable assembly and the change in the flow of repaired parts is very difficult to describe analytically and solve. One possible way of solving this kind of problems is the use of modeling and simulation.

The paper is structured as follows: there is an overview of the relevant literature in the area of repairable parts inventory management, 
and the application of simulation to solve the problem with the stock of repairable parts, followed by a brief explanation of operating parameters of a multi-echelon inventory system of maintainable parts. After the model and simulation description, the results of the simulation are given as well as their analysis. The paper also includes a brief conclusion.

Models of inventory management of maintainable parts have attracted the attention of many scientists and researchers who, in addition to theoretical considerations of the problem, have dealt with their practical applications in many fields. In a pioneering study in this area, Sherbrooke has developed a well-known METRIC (Multi-Echelon Technique for Recoverable Item Control) model for inventory management of multicomponent (multi-item) two-level inventory systems of maintainable parts (Sherbrooke, 1968). The demand for parts represents a complex Poisson process. In their books, Sherbrooke (2004), and Muckstadt (2005) gave a detailed review of the literature and developed models of inventory management of maintainable parts. The original METRIC model experienced a variety of modifications and extensions, such as in (Wang, et. al. 2000), (Wong, et. al. 2005), (Lau, et. al. 2006), (Huang, et. al. 2011). In order to test the validity and impact of modeling, a simulation model is used.

Simulations, as one of the most used techniques in the field of operations research, have been successfully applied for the analysis and solution of various problems in the area of inventory management of spare parts. A comprehensive review of the application of simulation techniques in the production and business is given by (Jahangirian, et. al. 2010). In (De Smidt-Destombes, et. al. 2011), the authors present a variant of a spare parts inventory model with cold stand-by redundancy on a system level. The model analysis of inventory management of spare parts, in one level or multilevel systems, based on the simulation is shown in (Lu, et. al. 2012), (Curtis, et. al. 2013), (Tako, 2012), (Klingebiel, 2012). Rossetti et. al., discussed the development and implementation of an object-oriented framework for simulating multi-echelon inventory systems (Rossetti, et. al. 2006). Two examples demonstrate a possibility of applying the developed object-oriented model.

Djordjevic et al, present the material and information flows in a twolevel inventory system of repairable assemblies with the aim of choosing the best variant of repaired assemblies flow (Djordjević, et. al. 2013). Applying the simulation technique to the inventory management model, the authors determined the values of the characteristics of inventory management functioning. The demand for repairable parts is modeled as a simple Poisson process, i.e. the time between two requests for assemblies is modeled by an exponential law of probability distribution with the parameter $\lambda$. The best solution for the flow of repaired assemblies was selected using the method of analytic hierarchy processes. 


\section{Characteristics of multi-echelon inventory system functioning}

This paper considers a two-level inventory system of repairable spare parts systems. The first level of supply consists of spare parts stored in peripheral warehouses, while the second level of supply consists of spare parts stored in a central warehouse. There is a workshop for the repair of defective repairable spare parts, located outside the central and peripheral warehouses. The peripheral warehouses are not connected to each other and can be filled only from the central warehouse. The central warehouse is filled from an inexhaustible source of supply. Requests for repairable spare parts by the user are sent only to the peripheral warehouses. The peripheral warehouses distribute repaired spare parts to the user, but only through the exchange with the defective spare parts. If some spare parts cannot be repaired, they are discarded. The defective spare parts that meet the requirements for repair are sent to the workshop and after repair, they are returned to the supply system. If in the peripheral warehouse, a required spare part is not in stock, unrealized demand is recorded and a backlog is formed. The central warehouse provides the peripheral warehouses with the specified assortment and a number of spare parts, where the partial delivery is permitted. The unrealized demand in the central warehouse is recorded and a backlog is formed.

As relevant for the functioning of the defined supply system of repairable spare parts, the following characteristics are distinguished:

coefficient of peripheral storage fill-rate,

the average waiting of demand,

total costs in the supply system.

In this study, we analyzed a one-component supply system of repairable spare parts. Based on this constraint these characteristics are determined.

The coefficient of storage filling is the ratio of the number of requests fulfilled without delay, relative to the total number of requests and it is given as:

$$
K_{p}=\frac{B_{1}}{B},
$$

where $B_{1}$ - the number of requests fulfilled without delay, and $B$ - the total number of requests. The average time of waiting in a queue is the ratio of the total waiting time and the number of requests in the queue. The average waiting time is calculated as:

$$
W=\frac{\sum_{i=1}^{n} W_{i}}{n},
$$


where $W_{\mathrm{i}}$ - waiting time of the ith request, $n$ - the number of requests in the queue. Total costs in the spare parts supply system are the sum of the costs of purchase of spare parts from an inexhaustible source, transport costs, storage costs and repair costs. The cost is suitable to be shown on an annual basis, and can be counted per structure for each element of the system. The total annual cost of the system $\left(L_{g}\right)$ is calculated as:

$$
L_{g}=L_{c g}+\sum_{j=1}^{n} L_{p_{j} g}+L_{r g} \quad\left[\frac{N J}{\text { year }}\right],
$$

where $L_{c g}$ - total annual costs of the central warehouse, $L_{p j g}$ - total annual cost of the jth peripheral warehouse, $L_{r g}$ the total annual cost of repair of spare parts.

\section{Description of the model}

The model consists of a central warehouse, four peripheral warehouses that keep repairable spare parts of a certain type and a workshop for the repair of defective parts. The peripheral warehouses operate on the model $(s, Q)$. When the stock level drops to the value of $s, a$ $Q$ value of the parts will be purchased. The time when the request is sent to the central warehouse is a random variable and is described by the probability distribution. Based on requirements, the peripheral warehouses deliver spare parts to the users if they are in stock. An unsatisfied demand is queued. The realization of requests in the queue is done on the principle of first - in first - out. At the same time with the delivery of the correct parts, defective parts are also received. Defective parts which meet the repair conditions to some extent are sent to the workshop for repair; if not, they are discharged. The time when defective spare parts are sent to the workshop is a random variable described by the probability distribution. On receiving the repaired spare parts or those from the central warehouse, if there is a queue, it is completely or partially emptied.

The workshop for repair does diagnostics and then, with a certain probability, repairs defective parts that are received from the peripheral warehouses. The time period of repair of a spare part is a random variable described by the probability distribution. Repaired spare parts are returned to the central warehouse or the peripheral ones, depending on the defined options for sending the repaired parts. The time of return of the repaired part from the workshop is a random variable described by the probability density distribution.

The central warehouse operates on the model $(S, T)$ for stock management. During the time period $\mathrm{T}$, the level of inventories is controlled. If at the time of control the inventory level is higher than the nominal level of 
$S$, then there is no order. If at the time of control there is a queue, the order of size $Y=S+R_{2}\left(R_{2}\right.$ is the length of the queue) is given to an inexhaustible source. If there is no queue, and the current inventory level is lower than the nominal one, the order of size $Y=S-X_{0}(T)$ is given, where $X_{0}(T)$ is the current inventory level. Filling the central warehouse from inexhaustible sources is complete, and the time to fill out is a random value described by the probability distribution. Upon receipt of assemblies by an inexhaustible source, the queue is emptied completely or partially. The central warehouse, on request, delivers assemblies to the peripheral storage, where there is a possibility of partial delivery. An unmet demand is placed in the queue. The queue is emptied by the FIFO principle. The exact time for sending the assemblies to the peripheral storage is a random variable described by the probability distribution. The central warehouse can also receive assemblies from the workshop, where the procedure is the same as when receiving parts from an inexhaustible source.

For a description of the model of a complex supply system of repairable assemblies, a form of an object-oriented model can be used, which uses the classes of models for describing the structure of the system and dynamic behaviour of the system - a description of the interdependence and interaction of some objects and a description of the internal "dynamics" of each object (Pejanovic, 2011).

For a description of the structure of the model, it is suitable to apply a class diagram. A class diagram for the defined model of the supply system of repairable assemblies is shown in Fig. 1. The diagram shows the class of objects with associated attributes and operations and relationships between the classes.

For a description of the interdependence and interaction of objects in the model, it is possible to apply the collaboration diagrams, which include a description of the context - the static structure of objects that are important to show the dynamics of operations and a description of the sequences of messages exchanged between objects, to realize the operation. An example of a collaboration diagram, which describes the receipt of parts in central and peripheral storage, is given in Fig 2.

For a description of the internal dynamics of these objects, state transitions diagrams are used, representing the state of objects, events and conditions that produce changes in conditions and actions that can "trigger," or messages that are generated during the transition from one state to another. As an example, Fig. 3 shows the state transition diagram for a workshop that repairs spare parts.

The experiments were performed on a model implemented in the software package MODSIM III (The Modular Simulation Language, today SIMSCRIPT). "The software package, MODSIM III is a modular language of block-structure and general purpose, which provides support for objectoriented programming, discrete-event simulation and animated graphics. It 
is intended for use in development of large-scale process-based models of discrete events simulation, through modular and object-oriented development techniques" (MODSIM III Reference manual, 1997).

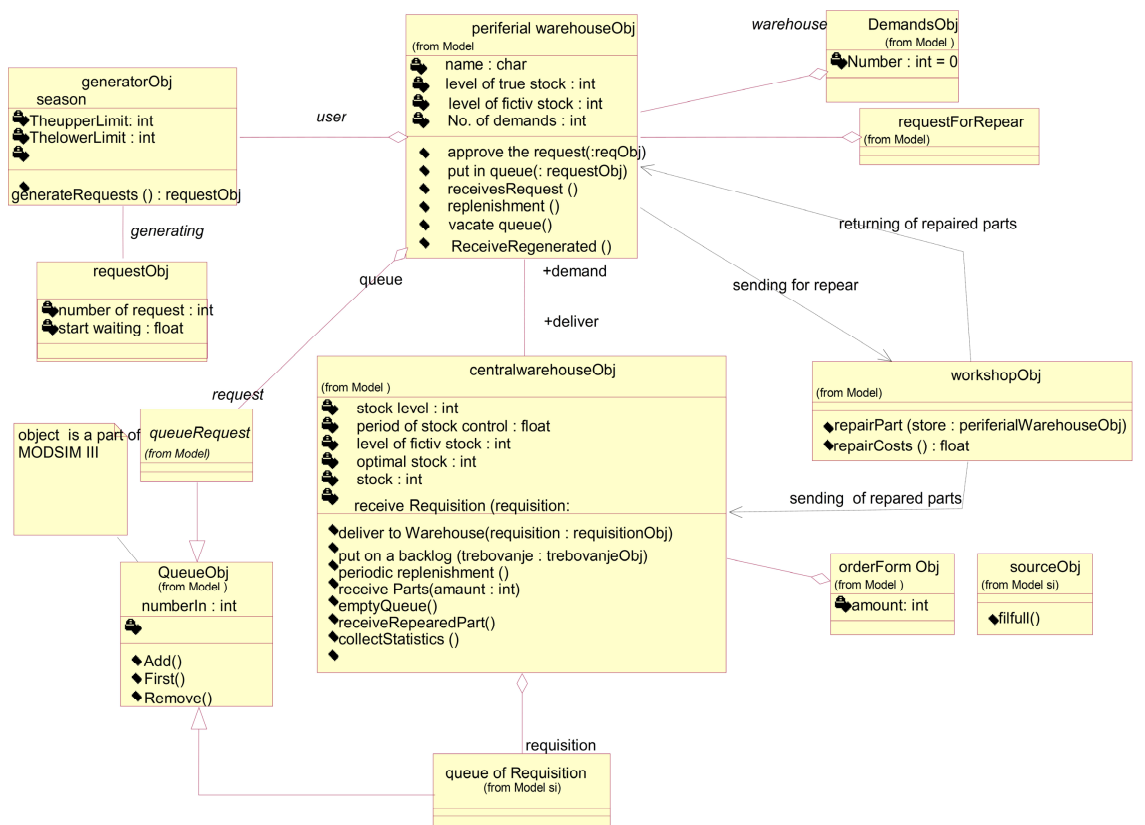

Figure 1 - Class diagram for the model of an inventory system of repairable parts Puc. 1 - Структурная диаграмма модели системы снабжения ремонтных запчастей Slika 1 - Strukturni dijagram modela sistema snabdevanja popravljivim delovima

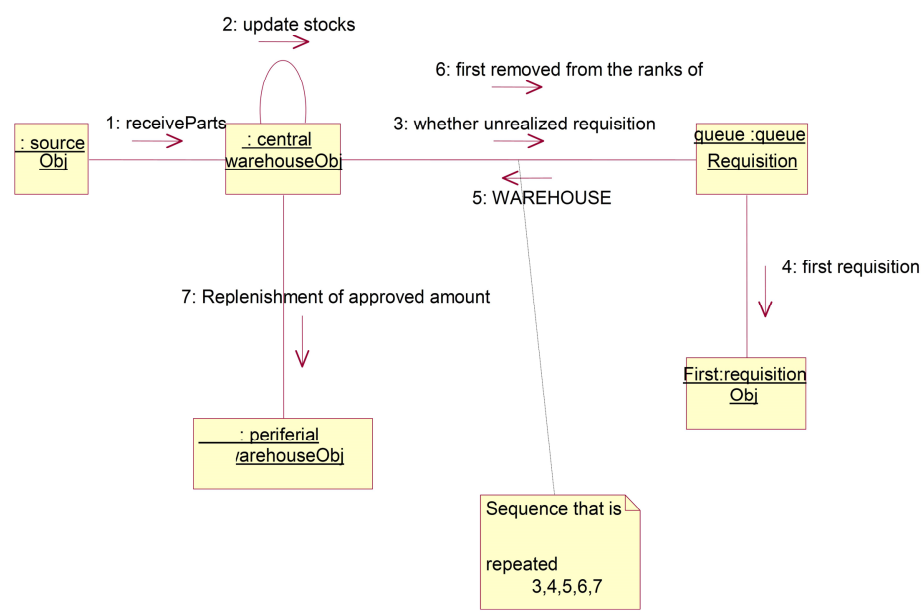

Figure 2 - Collaborative diagram: receipt of parts in central and peripheral storage Puc. 2 - Диаграмма кооперации: прием запчастей на центральный и периферийные Slika 2 - Kolaboracioni dijagram: prijem delova u centralno i periferno skladište склады 


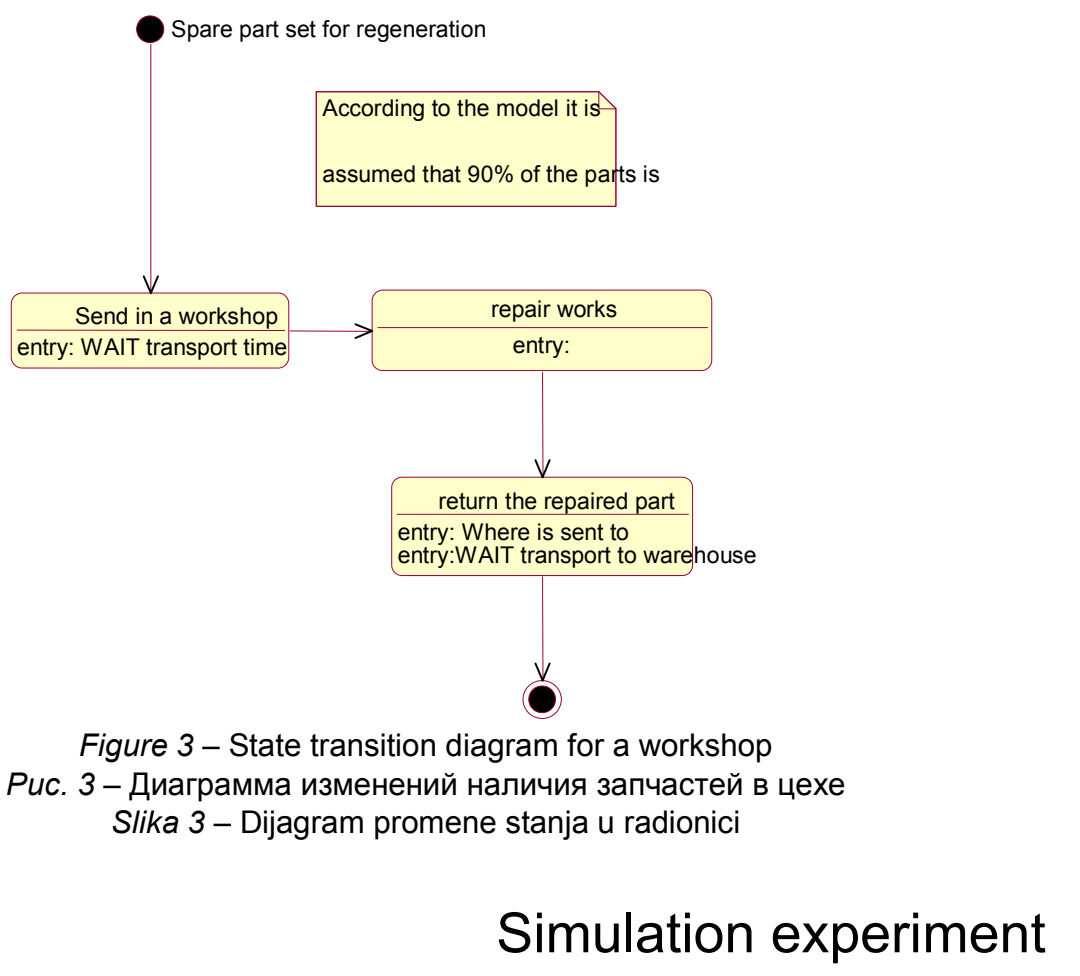

Prior to the experiment, it is necessary to do some preparations on the model and to plan experiments. The preparation includes calculation and determination of qualitative indicators for certain parameters. It is necessary to calculate and determine the values of the parameters so that the system is balanced and gives valid results. The following values of the parameters are defined:

The values of inventory levels in the central warehouse S2 vary between 7 and 23 with step 4 ,

The values of inventory levels in the peripheral warehouse S1 vary between: 4 and 12 with step 2 ,

Reordering point from the peripheral warehouse $s=1$,

Period of ordering from the central warehouse $T=15$ [day],

Price of the spare part $\mathrm{c}=10000[\mathrm{NJ} / \mathrm{pc}]$,

Fixed costs of ordering $\mathrm{T}=500[\mathrm{NJ} /$ orders],

Cost of transport ctr=16[NJ/km],

The cost of storage $\mathrm{i}=0.2[\mathrm{NJ} /$ year],

Cost of repair $\mathrm{cr}=(0.3-0.6) \mathrm{c}[\mathrm{NJ} / \mathrm{pc}]$,

Probability that the spare part will be sent for repair $\operatorname{Pr}=0.9$,

Probability that the spare part will be repaired $P o=0.75$, 
The distances between the central and peripheral warehouses as well as the distance between the workshop and the central or peripheral warehouse is 50 [km],

The time of sending orders from the peripheral to the central warehouse is subject to a normal probability distribution with parameters TNPC-N $(2 ; 0.5)$,

The time of sending spare parts from the central to peripheral warehouse is subject to a normal probability distribution with parameters TSCP-N $(3,0.5)$,

The time of sending spare parts for repair is subject to a normal probability distribution with parameters TSPR-N $(3,0.5)$,

The time of spare parts repair is described by normal probability distribution with parameters TSR-N $(5,1)$,

The time of return the spare parts after repair is subject to a normal probability distribution with parameters TSRPC-N $(2,0.5)$,

The time of filling in the central warehouse is subject to a normal probability distribution with parameters TNIC-N $(15 ; 2)$.

The variants for return of repaired spare parts are as follows:

- Variant V1 - all repaired parts are returned to the peripheral warehouse, from which they were sent for repair,

- Variant V2 - all repaired parts are sent to the central warehouse,

- Variant V3 - half of repaired spare parts are returned to the peripheral warehouse, from where it was sent for repair and the other half is sent to the central warehouse.

The size of demand in the first version Q1 is 3,5,7,9 and 11 spare parts. The second option is $Q 2=0.37 Q 1$. In the third variant, the size is $\mathrm{Q} 3=0.685 \mathrm{Q} 1$.

Demands for assemblies have a stream of seasonal changes. The time picture of the intensity of demands for assemblies has the following form:

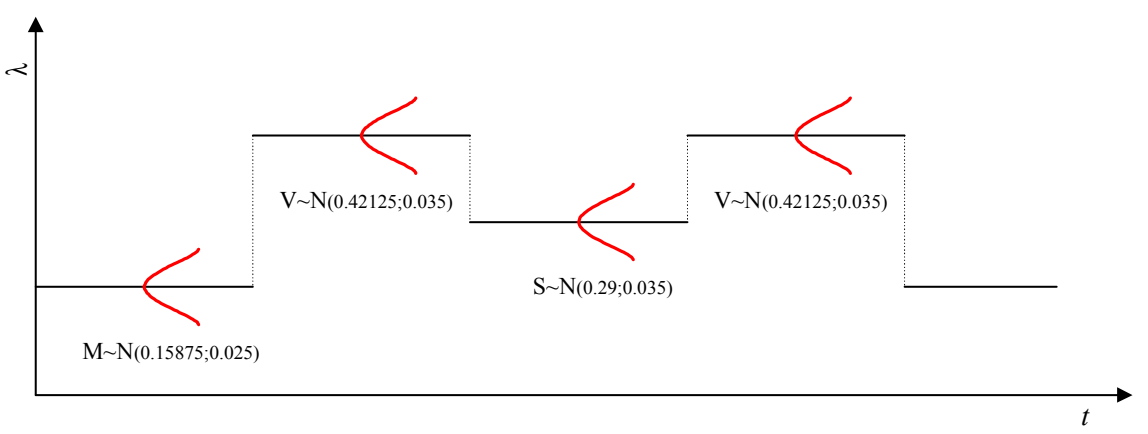

Figure 4 - Stream of requests for repairable parts

Puc. 4 - Вероятность заявки на ремонтные запчасти Slika 4 - Verovatnoća pojave zahteva za popravljivim delovima 


\section{Analysis of experimental results}

The changes in the mean values of the coefficient of availability of the peripheral storage $\mathrm{K}_{\mathrm{p}}$ depending on the value of the nominal level of inventories in the central (S2) and peripheral (S1) stores for all three variants of the flow of repaired components are shown in Figs. 5, 6, 7, 8 and 9.

In all graphs, it can be clearly observed that the mean value of the coefficient of availability of peripheral storage is greatest in the first option of sending reparaible assemblies, or when repaired assemblies are returned into the peripheral warehouse from which they were sent for repair. Somewhat lower are the mean values, $\mathrm{Kp}$ in the third option, while in the second option of sending reparaible assemblies the Kp mean values are the smallest. The results are logical, and they are an expected consequence of specific variants of the flow of repaired components. This is an indication of the validity of the functioning of the process model.

In variant $\mathrm{V} 1$, the mean value of $\mathrm{Kp}$ shows a slight deviation for all combinations of the nominal value of inventory levels in the peripheral (S1) and the central warehouse (S2). The difference between the maximum and minimum values of $\mathrm{Kp}$ is $6.15 \%$. Also, the increase in the nominal level of stock in the central warehouse does not lead to a significant increase in the coefficient of availability of the peripheral storage. For all values of S2, the increase in the value of S1 leads to an increase of the availability coefficient.

As noted above, the return of repaired components from the workshop to the central warehouse (variant V2) causes the least mean values of the coefficient of availability of peripheral warehouses. Reducing the value of the nominal level of the stock in the central warehouse, for low values of the nominal stock levels in the peripheral storage $(S 1=4)$, causes a significant reduction in the mean value of the availability coefficient, $\mathrm{Kp}$. The difference between the maximum and minimum values of $\mathrm{Kp}$ amounts to $32.29 \%$.

The third variant for the flow of repaired components gives the value of the coefficient of availability which is always between the value of $\mathrm{Kp}$ for the variants V1 and V2. By increasing the value of S2, the values of Kp slighty increase. A larger increase in $\mathrm{Kp}$ is achieved by increasing the nominal value of inventory levels in the peripheral warehouses S1. The difference between the maximum and minimum values of $\mathrm{Kp}$ amounts to $15.42 \%$.

Dependencies of the total annual cost on the change in the value of nominal stock levels in the central and peripheral storage is given in Figs. $10,11,12,13$ and 14. The variant of flow of repaired components from the workshop to peripheral warehouses V1 always gives the lowest value of the total annual cost of $\mathrm{Lg}$. Sending all repaired components from the workshop to the central warehouse (variant V2) gives the highest total annual cost of $\mathrm{Lg}$. It is not possible to draw a clear conclusion about the impact of changes in the value of nominal stock levels, S1 and S2, on the cost, Lg. 


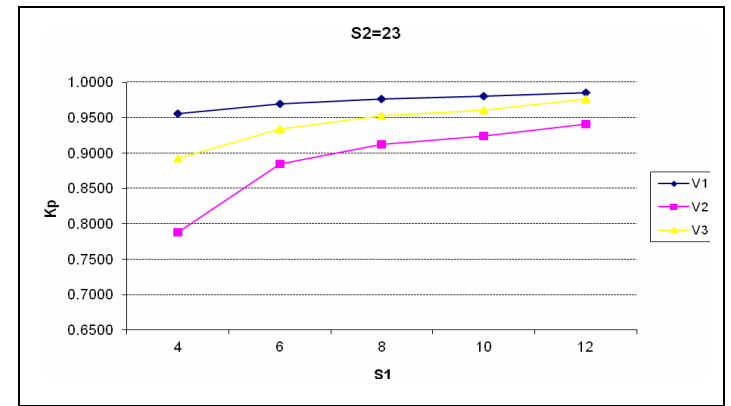

Figure $5-$ Values of $K_{p}$ for $S 2=23$

Puc. 5 - Значение $K_{p}$ za $S 2=23$

Slika $5-$ Vrednost $K_{p}$ za S2 $=23$

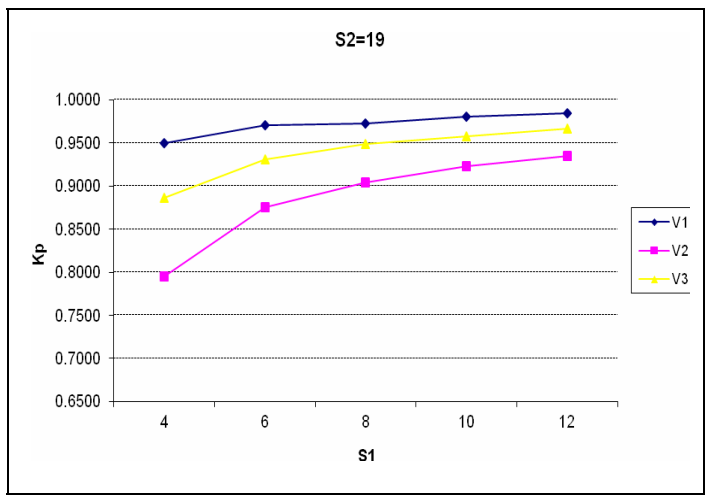

Figure $6-$ Values of $K_{p}$ for $S 2=19$

Puc. 6 - Значение $K_{p}$ za $S 2=19$

Slika $6-$ Vrednost $K_{p}$ za $S 2=19$

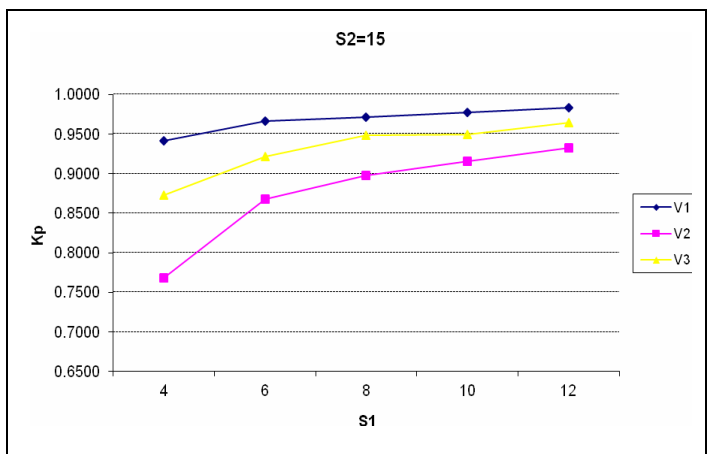

Figure $7-$ Values of $K_{p}$ for $S 2=15$

Puc. $7-$ Значение $K_{p}$ za $S 2=15$

Slika 7 - Vrednost $K_{p}$ za $S 2=15$ 


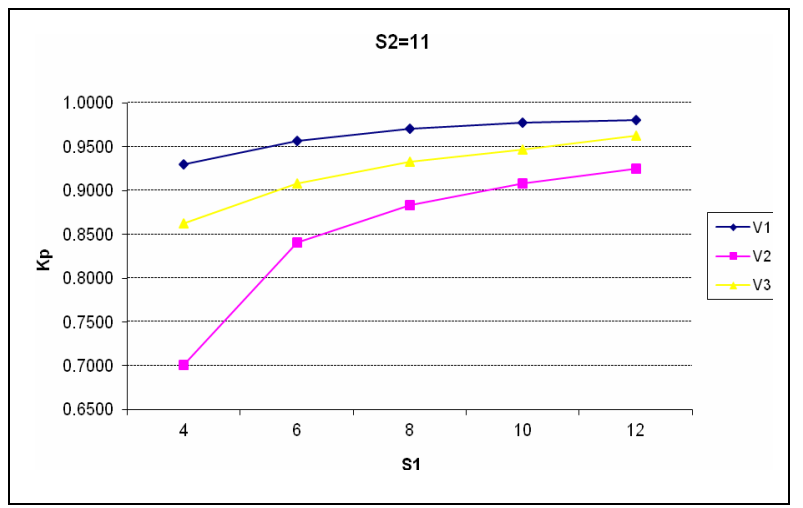

Figure $8-$ Values of $K_{p}$ for $S 2=11$

Puc. 8 - Значение $K_{p}$ za $S 2=11$

Slika 8 - Vrednost $K_{p}$ za $S 2=11$

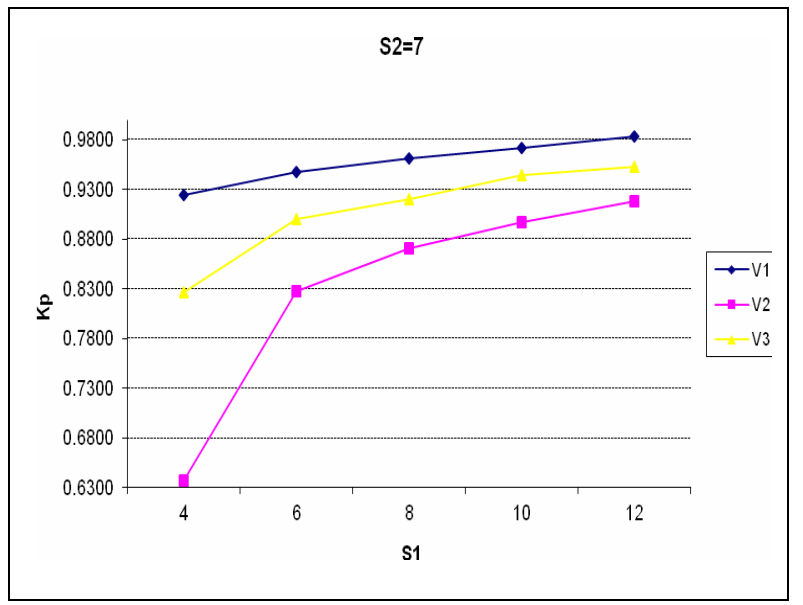

Figure 9 - Values of $K_{p}$ for $S 2=7$

Puc. 9 - Значение $K_{p}$ za $S 2=7$

Slika 9 - Vrednost $K_{p}$ za $S 2=7$

However, the greatest overall cost of the system for any variation in the flow of repaired components and for all the selected values of S2 is obtained for the value of $S 1=4$. It is only for variant V2 that, with the increase in the value of $S 1$, for all values of $S 2$, the value of total annual costs declines. The difference between the maximum and minimum values of the total annual cost for the variant $\mathrm{V} 1$ is $2.26 \%$, the variant $\mathrm{V} 2$ is $4.14 \%$, and the variant $\mathrm{V} 3$ is $2.28 \%$. 


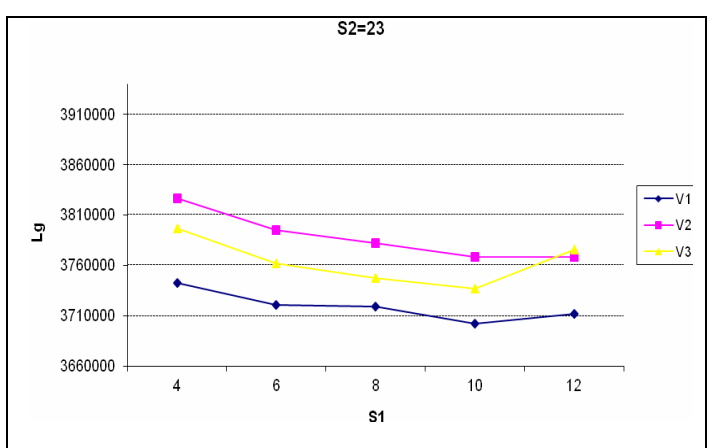

Figure $10-$ Values of $L$ for $S 2=23$

Puc. 10 - Значение $L$ для $S 2=23$

Slika 10 - Vrednost $L$ za S2=23

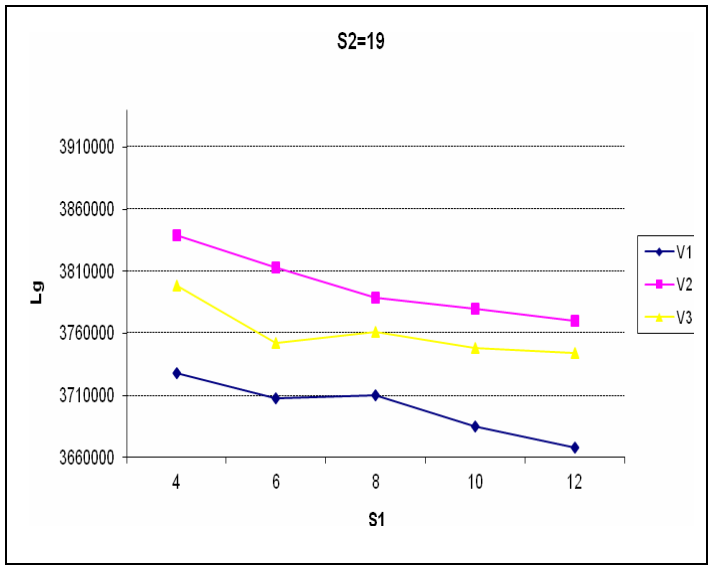

Figure $11-$ Values of $L$ for $S 2=19$

Puc. 11 - Значение $L$ для $S 2=19$

Slika 11 - Vrednost $L$ za S2 $=19$

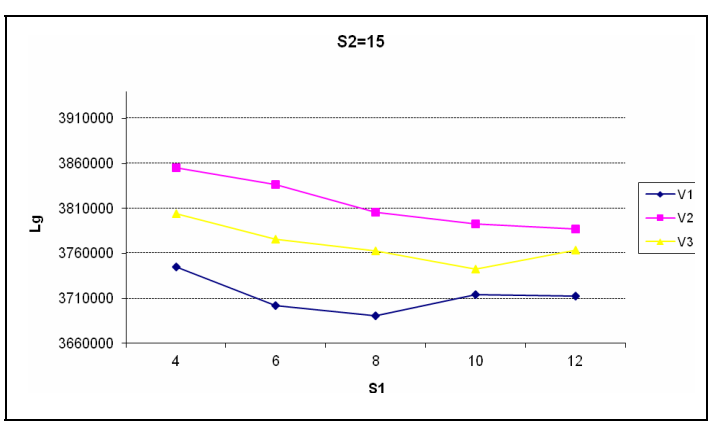

Figure $12-$ Values of $L$ for $S 2=15$

Puc. 12 - Значение $L$ для $S 2=15$

Slika 12 - Vrednost $L$ za $S 2=15$ 


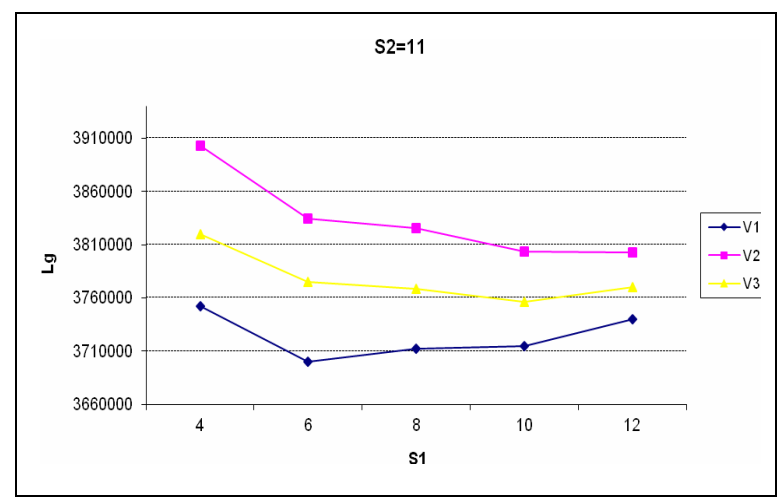

Figure $13-$ Values of $L$ for $S 2=11$

Puc. 13 - Значение $L$ для $S 2=11$

Slika 13 - Vrednost $L$ za $S 2=11$

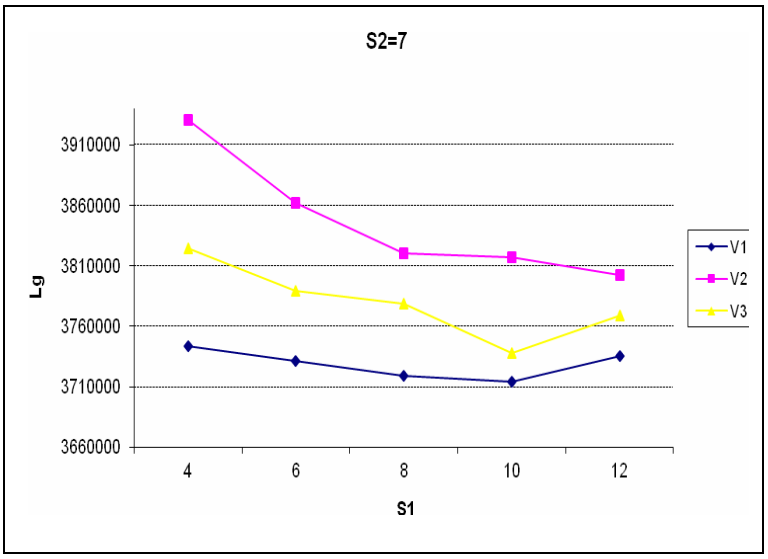

Figure $14-$ Values of $L$ for $S 2=7$

Puc. 14 - Значение $L$ для $S 2=7$

Slika 14 - Vrednost $L$ za S2=7

In Figs.15, 16, 17, 18 and 19, the change of the mean waiting time for the requests in the peripheral storage $W$, depending on the level of the nominal stock in the central and peripheral storage, is shown. Based on these results, it is not easy to draw a clear conclusion about the impact of variations in the flow of repaired components on the mean time queuing $\mathrm{W}$. The values of $\mathrm{W}$ range from 1.76 to 4 days, except for the variant $\mathrm{V} 2$ where, at low values of the nominal stock level $S 2=11$ and $S 2=7$ and low values $S 1=4$, the values of $W$ amount to 4,3 and 8 days, respectively. If the mentioned values are exceptions, it can be concluded that customers will wait for a spare part up to 4 days maximum. 


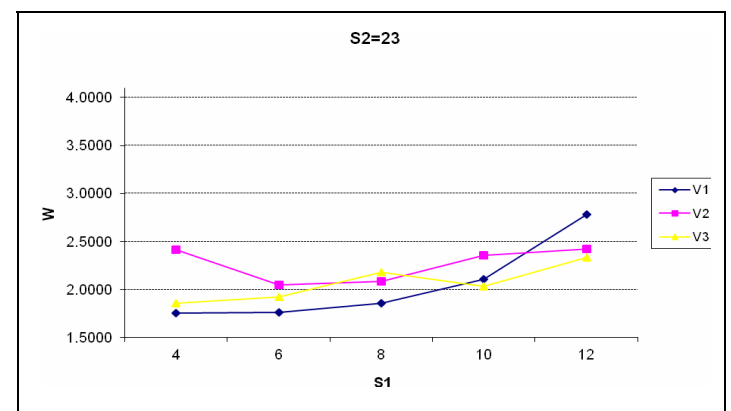

Figure $15-$ Values of $W$ for $S 2=23$

Puc. 15 - Значение $W$ для $S 2=23$

Slika $15-$ Vrednost $W$ za $S 2=23$

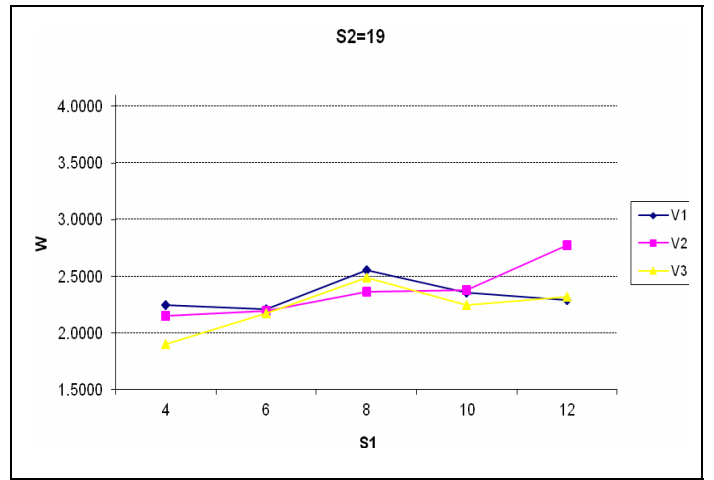

Figure $16-$ Values of $W$ for $S 2=19$

Puc. 16 - Значение $W$ для $S 2=19$

Slika $16-$ Vrednost $W$ za $S 2=19$

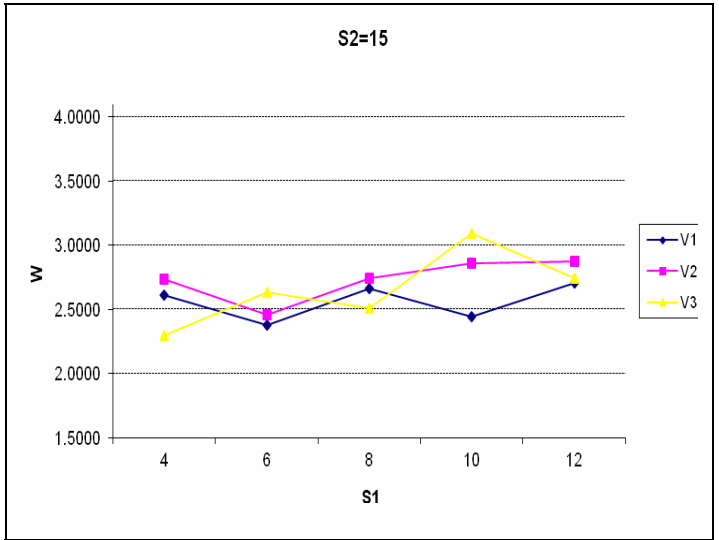

Figure $17-$ Values of $W$ for $S 2=15$ Puc. 17 - Значение $W$ для $S 2=15$ Slika $17-$ Vrednost $W$ za $S 2=15$ 


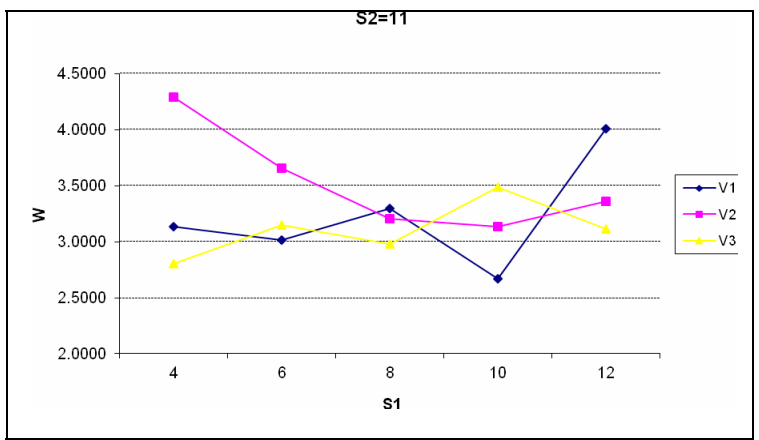

Figure $18-$ Values of $W$ for $S 2=11$

Puc. 18 - Значение $W$ для $S 2=11$

Slika 18 - Vrednost $W$ za $S 2=11$

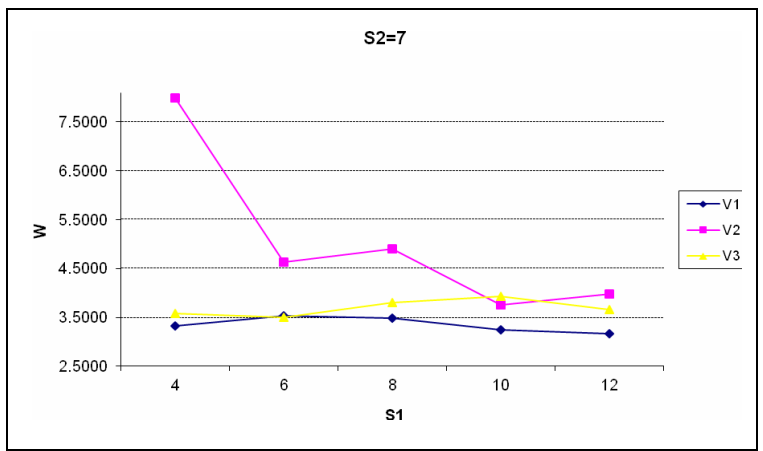

Figure $19-$ Values of $W$ for $S 2=7$

Puc. 19 - Значение $W$ для $S 2=7$

Slika 19 - Vrednost $W$ za $S 2=7$

The mean values of the inventory levels in the warehouses Ypi $(i=1, \ldots, 4), Y c$, and $Y s$ of the system, are given in Tab. 1. The return of repaired components to peripheral storage leads to an increase in the mean value of the stock in the peripheral warehouses, which is the expected result. This, however, results in an increase in the mean value of the total inventory of the system which, for all combinations of the values $\mathrm{S} 1$ and S2, is greater than the value obtained by the variants of V1 and $\mathrm{V} 2$. The return of repaired components to the central storage results in the lowest average value of stocks in the stock system of repairable parts. The increase in the nominal value of the stock at the central warehouse S2 does not necessarily lead to an increase in the mean value of inventory in the system Ys. There is no statistically significant difference between the mean values of the stocks in the peripheral warehouses, Ypi $(i=1, . ., 4)$ for any value of $S 2$ and the variation of flow of repaired components. 
Table 1 - Average levels of inventory in the central warehouse, the peripheral warehouse, and in the whole system

Таблица 1 - Средний уровень запасов на центральном и периферийном складах и в общей системе

Tabela 1 - Srednji nivo zaliha u centralnom i perifernom skladištu, i u celokupnom sistemu

\begin{tabular}{|c|c|c|c|c|c|c|c|c|c|c|c|c|c|c|c|c|c|c|c|}
\hline \multirow{2}{*}{ S2 } & \multirow{2}{*}{$S 1$} & \multicolumn{6}{|c|}{ V1 } & \multicolumn{6}{|c|}{ V2 } & \multicolumn{6}{|c|}{ V3 } \\
\hline & & $Y_{p 1}$ & $Y_{p 2}$ & $Y_{p 3}$ & $Y_{p 4}$ & $Y_{c}$ & Ys & $Y_{p 1}$ & $Y_{p 2}$ & $Y_{p 3}$ & $Y_{p 4}$ & $Y_{c}$ & $Y_{s}$ & $Y_{p 1}$ & $Y_{p 2}$ & $Y_{p 3}$ & $Y_{p 4}$ & $Y_{c}$ & $Y_{s}$ \\
\hline \multirow{5}{*}{23} & 4 & 5 & 5 & 5 & 5 & 20 & 40 & 2 & 2 & 2 & 2 & 20 & 28 & 3 & 3 & 3 & 3 & 20 & 32 \\
\hline & 6 & 7 & 7 & 7 & 7 & 22 & 50 & $\checkmark$ & 3 & 3 & 3 & 21 & 33 & 5 & 5 & 5 & 5 & 22 & 42 \\
\hline & 8 & 9 & 10 & 10 & 9 & 26 & 64 & 5 & 5 & 5 & 5 & 24 & 44 & 7 & 7 & 7 & 6 & 26 & 53 \\
\hline & 10 & 11 & 13 & 13 & 11 & 27 & 75 & 6 & 6 & 6 & 6 & 24 & 48 & 8 & 8 & 8 & 8 & 28 & 60 \\
\hline & 12 & 14 & 16 & 14 & 13 & 31 & 88 & 8 & 8 & 7 & 8 & 31 & 62 & 11 & 11 & 11 & 10 & 32 & 75 \\
\hline \multirow{5}{*}{19} & 4 & 5 & 6 & 6 & 6 & 19 & 42 & 2 & 2 & 2 & 2 & 17 & 25 & 3 & 3 & 3 & 3 & 18 & 30 \\
\hline & 6 & 7 & 8 & 8 & 8 & 21 & 52 & 0 & 3 & 3 & 3 & 17 & 29 & 5 & 5 & 5 & 5 & 18 & 38 \\
\hline & 8 & 10 & 10 & 11 & 9 & 21 & 61 & 5 & 5 & 5 & 5 & 21 & 41 & 6 & 7 & 6 & 7 & 23 & 49 \\
\hline & 10 & 12 & 13 & 13 & 11 & 26 & 75 & 0 & 6 & 6 & 6 & 20 & 44 & 9 & 9 & 8 & 9 & 26 & 61 \\
\hline & 12 & 14 & 15 & 14 & 15 & 28 & 86 & 8 & 8 & 7 & 8 & 29 & 60 & 11 & 11 & 11 & 10 & 29 & 72 \\
\hline \multirow{5}{*}{15} & 4 & 6 & 5 & 6 & 6 & 16 & 39 & 2 & 2 & 2 & 2 & 13 & 21 & 3 & 3 & 3 & 3 & 15 & 27 \\
\hline & 6 & 8 & 8 & 8 & 8 & 17 & 49 & 3 & 3 & 3 & 3 & 17 & 29 & 5 & 5 & 5 & 5 & 21 & 41 \\
\hline & 8 & 9 & 11 & 12 & 9 & 17 & 58 & 5 & 5 & 5 & 5 & 21 & 41 & 7 & 7 & 7 & 7 & 20 & 48 \\
\hline & 10 & 11 & 14 & 13 & 13 & 23 & 74 & 6 & 7 & 6 & 6 & 22 & 47 & 9 & 9 & 8 & 9 & 24 & 59 \\
\hline & 12 & 13 & 19 & 17 & 15 & 29 & 93 & 8 & 8 & 8 & 8 & 24 & 56 & 12 & 11 & 10 & 11 & 30 & 74 \\
\hline \multirow{5}{*}{11} & 4 & 5 & 6 & 6 & 6 & 13 & 36 & 2 & 2 & 1 & 2 & 11 & 18 & 3 & 3 & 3 & 3 & 15 & 27 \\
\hline & 6 & 8 & 8 & 8 & 8 & 16 & 48 & 3 & 3 & 3 & 3 & 14 & 26 & 5 & 5 & 5 & 5 & 18 & 38 \\
\hline & 8 & 12 & 10 & 12 & 11 & 19 & 64 & 5 & 5 & 5 & 5 & 16 & 36 & 7 & 7 & 7 & 7 & 18 & 46 \\
\hline & 10 & 14 & 15 & 14 & 12 & 15 & 70 & 6 & 6 & 6 & 6 & 17 & 41 & 8 & 8 & 9 & 10 & 21 & 56 \\
\hline & 12 & 13 & 16 & 16 & 14 & 19 & 78 & 8 & 8 & 8 & 9 & 24 & 57 & 11 & 11 & 11 & 11 & 20 & 64 \\
\hline \multirow{5}{*}{7} & 4 & 6 & 7 & 6 & 6 & 12 & 37 & 1 & 2 & 2 & 2 & 8 & 15 & 3 & 3 & 3 & 3 & 11 & 23 \\
\hline & 6 & 9 & 8 & 9 & 8 & 11 & 45 & 3 & 3 & 3 & 3 & 14 & 26 & 5 & 6 & 5 & 6 & 17 & 39 \\
\hline & 8 & 11 & 12 & 12 & 11 & 15 & 61 & 5 & 5 & 5 & 5 & 17 & 37 & 8 & 7 & 7 & 8 & 19 & 49 \\
\hline & 10 & 13 & 16 & 16 & 12 & 17 & 74 & 6 & 7 & 7 & 7 & 19 & 46 & 10 & 9 & 9 & 10 & 21 & 59 \\
\hline & 12 & 14 & 19 & 16 & 15 & 17 & 81 & 8 & 8 & 8 & 8 & 19 & 51 & 13 & 13 & 11 & 11 & 23 & 71 \\
\hline
\end{tabular}

\section{Conclusion}

Knowledge of the operating parameters for a multi-ecshelon repairable parts inventory system is necessary for managing such a system. Determining the values of the operating parameters and testing the impact of changes in certain parameters on the parameter values is a 
complex problem that can be solved by using modeling and simulation. Object-oriented models allow the description of a multi-echelon inventory system, suitable for the development of a process simulation model.

In the considered two-echelon, one-component inventory system of repairable parts, one can clearly see the influence of the flow of repaired components on the mean availability ratio of the peripheral storage $\mathrm{Kp}$, and the value of the total annual cost of the system Lg. However, it is not possible to draw a clear conclusion regarding the impact of the flow of repaired components on the mean waiting time $\mathrm{W}$, but it is possible to assume the mean value of maximum waiting time for spares.

Taking into account the results obtained by the simulation, and from the standpoint of rational management of the monitored supply system, a logical choice is a selection of an optimum flow of repaired components from the workshop to the peripheral warehouse V1.

\section{References}

de Smidt-Destombes, K.S., van Elst, N.P., Barros, A.I., Mulder, H., \& Hontelez, J.A.M. 2011. A spare parts model with cold-standby redundancy on system level. Computers \& Operations Research, 38(7), pp.985-991. doi:10.1016/j.cor.2010.09.006

Djordjevic, S.M., Zrnic, Đ.N., Milicevic, R.M., \& Miskovic, V.V. 2013. Information and Material Flow Modeling in System of Parts Regeneration In Multi-level Supply System. Technical Gazette, 20(5), pp.861-896.

Huang, Q., \& Hu, B. 2011. Simulation Model of Multi-Echelon Closed Supply Chain for Spare Parts, Intelligent Systems and Applications (ISA). In: Proceedings of 3rd International Workshop on IEEE.

Iwata, C., \& Mavris, D. 2013. Object-Oriented Discrete Event Simulation Modeling Environment for Aerospace Vehicle Maintenance and Logistics Process. Procedia Computer Science, 16, pp.187-196. doi:10.1016/j.procs.2013.01.020

Jahangirian, M., Eldabi, T., Naseer, A., Stergioulas, L.K., \& Young, T. 2010. Simulation in manufacturing and business: A review. European Journal of Operational Research, 203(1), pp.1-13. doi:10.1016/j.ejor.2009.06.004

Klingebiel, K., \& Li, C. 2012. In Advances in Intelligent Modelling and Simulation.Berlin: Springer., pp.165-197.

Lau, H.C., Song, H., See, C.T., \& Cheng, S.Y. 2006. Evaluation of time-varying availability in multi-echelon spare parts systems with passivation. European Journal of Operational Research, 170(1), pp.91-105. doi:10.1016/j.ejor.2004.06.022

Lei, L., \& Jiangping, Y. 2012. An Inventory Model for Allocating Repairable Spares Based on Three-echelon Supply Relationship. Quality, Reliability, Risk, Maintenance, and Safety Engineering (ICQR2MSE). In: Proceedings of the International Conference on IEEE.

Milićević, M. 2000. Management of Spare Parts Supply in Hierarchical Organizations.Belgrade: Military Technical Academy.

MODSIM III Reference Manual 1997. CACI Products Company.

Muckstadt, J. 2005. Analysis and Algorithms for Service Parts Supply Chains. USA: Springer.

Pejanovic, J.M. 2011. Razvoj informacionih sistema u internet okruženju korišćenjem softverskih komponenti sa posebnim osvrtom na primenu u vojnoj organizaciji. Vojnotehnički glasnik/Military Technical Courier, 59(1), pp.121-148. 
Rossetti, M., Miman, M., Varghese, V., \& Xiang, Y. 2006. An Object-Oriented Framework for Simulating Multi-echelon Inventory Systems. In: Proceedings of the 2006 Simulation Conference. Monterey, USA.

Sherbrooke, C.C. 1968. Metric: A Multi-Echelon Technique for Recoverable Item Control. Operations Research,16(1), pp.122-141. doi:10.1287/opre.16.1.122

Sherbrooke, C. 2004. Optimal Inventory Modeling of Systems: Multi-Echelon Techniques, 2nd. Boston: Kluwer.

Tako, A.A., \& Robinson, S. 2012. The application of discrete event simulation and system dynamics in the logistics and supply chain context. Decision Support Systems, 52(4), pp.802-815. doi:10.1016/j.dss.2011.11.015

Wang, Y., Cohen, M.A., \& Zheng, Y. 2000. Two-Echelon Repairable Inventory System with Stocking-Center-Dependent Depot Replenishment Lead Times. Management Science, 46(11), pp.1441-1453. doi:10.1287/mnsc.46.11.1441.12081

Wong, H., van Houtum, G.J., Cattrysse, D., \& van Oudheusden, D. 2005. Simple, efficient heuristics for multi-item multi-location spare parts systems with lateral transshipments and waiting time constraints. Journal of the Operational Research Society, 56(12), pp.1419-1430. doi:10.1057/palgrave.jors.2601952

\section{ПОТОК РЕМОНТНЫХ ЗАПЧАСТЕЙ В МУЛЬТИЭШЕЛОННОЙ СИСТЕМЕ СНАБЖЕНИЯ}

Милич Р. Миличевич, Влада С. Соколович, Марьян А. Миленков

Университет обороны в г. Белград, Военная академия

ОБЛАСТЬ: вычислительная техника, информатика, теория принятия решений и количественные методы

ВИД СТАТЬИ: оригинальная научная статья

ЯЗЫК СТАТЬИ: английский

\section{Резюме:}

В данной работе рассматривается проблема, касающаяся изменений стоимости закупок в работе двухуровневой системы снабжения запчастей, в зависимости от оборота запчастей в системе снабжения.

Проведен анализ влияния на поток регенерированных компонентов, в зависимости от значения коэффрициента заполнения перифрерийных складов, общих затрат и среднего времени ожидания на периферийных складах, относительно номинальной стоимости размещения в центральном и периферийном складах.

Спрос на запчасти в периферийных складах зависит оm ceзонных изменений, которые моделируются в соответствии с функцией вероятности.

Ключевые слова: моделирование, мультиэшелонная система снабжения, ремонтные запчасти, симуляция, запчасти. 
TOK POPRAVLJIVIH REZERVNIH DELOVA U MULTIEŠELONSKOM SISTEMU SNABDEVANJA

Milić R. Milićević, Vlada S. Sokolović, Marjan A. Milenkov

Univerzitet odbrane u Beogradu, Vojna akademija

OBLAST: računarstvo i informatika, teorija odlučivanja i kvantitativne metode VRSTA ČLANKA: originalni naučni članak

JEZIK ČLANKA: engleski

\section{Sažetak:}

$U$ radu se razmatra problem promene vrednosti odabranih parametara na rad dvonivovskog sistema snabdevanja rezervnim delovima, zavisno od protoka rezervnih delova u sistemu snabdevanja. Analiziran je uticaj na tok regenerisanih komponenti u zavisnosti od vrednosti koeficijenta popunjenosti perifernih skladišta, ukupnih troškova i prosečnog vremena čekanja u redu u perifernim skladištima, za različite nominalne vrednosti stoka u centralnom i perifernom skladištu. Potražnja za rezervnim delovima u perifernim skladištima zavisi od sezonskih promena, koje su modelovane sa odgovarajućom funkcijom verovatnoće.

Ključne reči: modeliranje, multiešelonski sistem snabdevanja, popravljivi rezervni delovi, simulacija, rezervni delovi.

Datum prijema članka / Дата получения работы / Paper received on: 30. 04. 2015.

Datum dostavljanja ispravki rukopisa / Дата получения исправленной версии работы /

Manuscript corrections submitted on: 04. 06. 2015.

Datum konačnog prihvatanja članka za objavljivanje / Дата окончательного

согласования работы / Paper accepted for publishing on: 06. 06. 2015.

(c) 2016 Autori. Objavio Vojnotehnički glasnik / Military Technical Courier (www.vtg.mod.gov.rs, втг.мо.упр.срб). Ovo je članak otvorenog pristupa i distribuira se u skladu sa Creative Commons licencom (http://creativecommons.org/licenses/by/3.0/rs/).

(c) 2016 Авторы. Опубликовано в "Военно-технический вестник / Vojnotehnički glasnik / Military Technical Courier" (www.vtg.mod.gov.rs, втг.мо.упр.срб). Данная статья в открытом доступе и распространяется в соответствии с лицензией "Creative Commons" (http://creativecommons.org/licenses/by/3.0/rs/).

(C) 2016 The Authors. Published by Vojnotehnički glasnik / Military Technical Courier (www.vtg.mod.gov.rs, втг.мо.упр.срб). This article is an open access article distributed under the terms and conditions of the Creative Commons Attribution license (http://creativecommons.org/licenses/by/3.0/rs/).

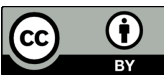

